\title{
Collection, Consumption, and Sale of Lusala (Dioscorea hirtiflora)—a Wild Yam—by Rural Households in Southern Province, Zambia
}

\author{
Donald Zulu ${ }^{1,2}$, Richard H. Ellis ${ }^{*, 1}$, and Alastair Culham ${ }^{2}$ \\ ${ }^{1}$ School of Agriculture, Policy and Development, University of Reading, Reading, UK \\ ${ }^{2}$ School of Biological Sciences, University of Reading, Reading, UK \\ *Corresponding author; e-mail: r.h.ellis@reading.ac.uk
}

\begin{abstract}
Dioscorea hirtiflora Benth. is an indigenous wild edible tuberous climbing plant native to Zambia. Known as lusala, the tubers are sold in markets across southern Zambia. Lusala collection, consumption, and trade were investigated through interviews with rural households (four districts) and market traders (three towns), and supplementary focus group discussions. Of 278 households interviewed, high proportions collected (83\%), consumed (96\%), and sold (59\%) lusala, not varying amongst district or wealth category. Lusala populations were perceived to be declining in the wild by $79 \%$ of households. Tuber collection, largely by females and mainly from March to September, peaked in April when households engaged in each activity and collected $27.9 \mathrm{~kg}$, consumed $12.0 \mathrm{~kg}$, and sold $35.7 \mathrm{~kg}$ (from 129, 108, and 69 reporting households, respectively) that month, regardless of district, wealth category, or gender. Those sales provided an average household income of USD 16 in April 2017. In August 2017, each market trader purchased an average of $899 \mathrm{~kg}$ for USD 383. Local knowledge of D. hirtiflora was considerable. Lusala collected from forests is an important edible wild tuber in the local economy of the Southern Province of Zambia; it provides a seasonally important food supply and income to rural households and supplies demand for urban populations.
\end{abstract}

Key Words: Dioscorea hirtiflora Benth., tubers, non-timber forest products, wild edible plants, rural households, markets, Zambia.

\section{Introduction}

Non-timber forest products (NTFPs) contribute to household subsistence needs and cash income and provide a safety net in times of disaster from drought, pests, or disease-causing crop failures (Murali et al. 1996; Timko et al. 2010). Generally, NTFPs are biological products from wild species harvested by humans from diverse landscapes for consumptive and non-consumptive uses with most benefits accruing to local actors (Shackleton et al. 2011). Most NTFPs have traditional and cultural significance and value (Heubach et al. 2011). They are important to livelihoods (Bakkegaard et al. 2017; Heubach et al. 2011; Paumgarten and Shackleton 2009). Often, there are inadequate data

\footnotetext{
${ }^{1}$ Received 15 March 2018; accepted 6 December 2018; published online 25 January 2019
}

to understand the value of environmental resources to rural households, especially in Africa, but analyses have shown that environmental resources contribute substantially to rural incomes, particularly to poorer households in proportional terms (Angelsen et al. 2014; Cavendish 2000). Moreover, women tend to play a larger role in collecting wild plant resources for household use (Cavendish 2000; Sunderland et al. 2014).

Non-timber forest products provide many necessities, including food, medicine, fodder, and energy. Wild edible plants (WEPs) are an important type of NTFPs. They contribute significantly to household food and support about 300 million people in developing countries (Bharucha and Pretty 2010). They also improve food diversity in rural households (Bakkegaard et al. 2017; Paumgarten and Shackleton 2009; Shackleton and Shackleton 2004; Shelef et al. 2017). Some 391,000 species of plants are documented worldwide, of which 
5538 (cultivated and wild) have been used as human food (RBG Kew 2016). They include indigenous fruits, vegetables, edible herbs, wild cereals and grains, wild mushrooms, and wild roots and tubers (Heubach et al. 2011). Generally, populations of WEPs are declining along with the associated traditional knowledge (Padulosi et al. 2013).

Dioscorea hirtiflora Benth. (lusala, busala, or lwidi in the Tonga language) is a tuberous climbing WEP indigenous to Zambia. This wild yam normally produces about one to six cylindrical, vertically descending tubers that grow to about $50 \mathrm{~mm}$ in diameter (Wilkin 2001). Its seasonal presence in most district markets in southern and central Zambia, anecdotal evidence, and an initial scoping study suggest it may be an important food plant there. The contribution of NTFPs to the national economy in Zambia is not captured in official statistics and national accounts. Nonetheless, the potential for D. hirtiflora to contribute to rural livelihoods in Zambia has been recognized (Forestry Department 2016).

Dioscorea hirtiflora occurs in the wild with very limited domestication. Its presence is threatened by considerable deforestation in Zambia, some 250,000 ha to 300,000 ha per annum (Mukosha and Siampale 2009). Whilst fuelwood collection, timber harvesting, forest clearance for crop production, urbanization, and industrialization are contributing factors, charcoal production is the greatest single driver of deforestation in Zambia (Vinya et al. 2011). Rural poverty is high in Zambia (76.6\%), and $60 \%$ of the country's population (a total of over 16 million) is rural-based (Central Statistical Office 2015). Estimating the value of $D$. hirtiflora to rural households in Zambia and their perceptions of the status of populations of this WEP would indicate its potential to alleviate rural poverty and provide a foundation for appropriate interventions (conservation, sustainable gathering, domestication, business support) and policy to first safeguard and second enhance its value to the nation.

We surveyed the perceived state of wild populations, tuber collection, consumption, and trade amongst rural households and also market traders in selected rural districts of Zambia's Southern Province to discover whether or not $D$. hirtiflora was important and considered to be at risk. We hypothesized that this WEP (1) is widely collected, (2) is an important supplement to rural household diets, and (3) contributes to rural household income. We also explored the scale of these activities and lusala's value with rural households and market traders.

\section{Methods}

\section{STUDY AREA}

The study was conducted in the Southern Province of Zambia (Fig. 1), a total area of about $85,300 \mathrm{~km}^{2}$. Its population was $1,589,926$ in the 2010 Census, about $12 \%$ of the total Zambian population then (Central Statistical Office 2012). About $68 \%$ of the Southern Province population lives below the poverty line compared to the national average of $61 \%$. Poverty in Zambia is more pronounced in rural than urban areas: in 2010, rural and urban poverty was $78 \%$ and $28 \%$, respectively. Some $75 \%$ of the population of Southern Province is rural-based (Central Statistical Office 2012). The Tonga ethnic group is the second largest grouping (14\%) after Bemba (21\%) in Zambia and the main group in Southern Province. Rural households are generally under the authority of a village headman who represents the traditional chief. Livelihoods depend upon mixed farming - with cattle, goats, and poultry as well as maize, groundnuts, cowpea, sweet potato, cassava, sunflower, soya beans, cotton, and tobacco-supplemented by natural resources. The typical smallholder farm size is about 1 ha to 5 ha (Baudeon et al. 2007).

The rural household survey sites were the Pemba, Itezhi Tezhi, Namwala, and Kalomo districts of Zambia's Southern Province (Fig. 1). These four districts, especially the rural parts, are inhabited mostly by the Tonga and Ila ethnic groups. They are known anecdotally to collect $D$. hirtiflora for food and income. These districts were selected partly on this preliminary evidence of lusala use and accessibility, but also to provide a broad geographic foundation to the study across this province and to test for possible variation in lusala use amongst them.

The region has three distinct seasons: a warm rainy season from November to April, a cool dry season from May to August, and a hot dry season from September to October (Speybroeck et al. 2002). Annual rainfall is about $800 \mathrm{~mm}$ (Muliokela 1995). Rainfall declined over the 1950-1990 period, with a 10-year annual rainfall mean of $879 \mathrm{~mm}$ for 1951-1960 declining to $755 \mathrm{~mm}$ for 1981-1990 (Tiffen and Mulele 1994). The seasonal rainfall duration also declined from 202 days in the 1979/1980 rainy season to 135 days in 1999/2000 (Hachigonta et al. 2008). The vegetation in the province is dominated by the southern 


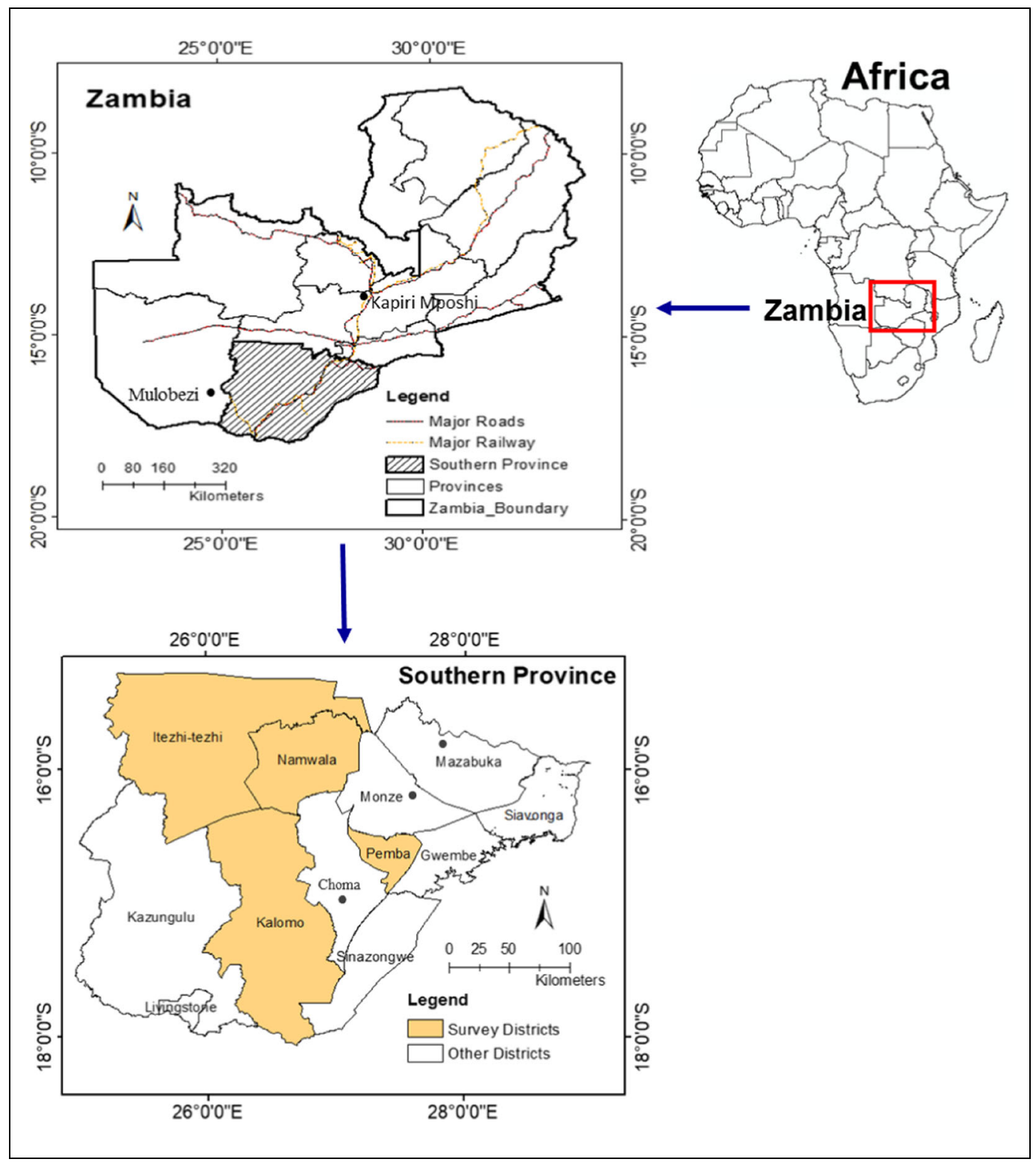

Fig. 1. Maps of Africa, Zambia, and its Southern Province. The latter shows the four districts where rural households were surveyed and the three towns (filled circle) where market traders were interviewed (n.b. these towns have the same name as their district). In the national map, Kapiri Mposhi and Mulobezi are towns (filled circle) in Central Province and Western Province, respectively (cited by market traders as extreme sources of tubers).

miombo woodlands and grasslands (Speybroeck et al. 2002). Most of the area, especially the central region of the province, is located on the Southern Plateau of Zambia, which is part of the Central African Plateau (Shitumbanuma et al. 2007).

\section{SAMPLING STRATEgY}

The Southern Province was selected based on anecdotal evidence of the use of the tubers for food. Four out of the 11 districts (Central Statistical 
Office 2012) were selected at random (by random number generator). A minimum of three villages was sampled in each district. The village list was the sampling frame. Respondents were sampled randomly from each village. Southern Province was estimated to have 292,179 households (Central Statistical Office 2012): a sample of 385 households (confidence level 95\%; margin of error 5\%) was targeted, using the method of Krejcie and Morgan (1970) to determine sample size.

\section{Data Collection}

Free, prior informed consent to conduct the research was sought from local leaders and stakeholders (village headman, lead farmers, and agricultural extension officers) in each village initially and then from each research participant. All interviews and discussions were conducted in Tonga (the local language) by and amongst Zambian nationals. These, and the records thereof, were confidential. Two structured household questionnaires (one for rural households in villages, one for market traders in towns) and focus group discussions were designed according to standard formats with sections on household composition and characterization, assets, and socioeconomics (Angelsen and Lund 2011) following the procedures of the University of Reading Research Ethics Committee. Four field assistants were recruited and trained to assist in data collection. Each questionnaire was piloted first before finalizing.

\section{Rural Household Survey}

Local people are best placed to accurately assess the relative wealth of their communities (Kalaba et al. 2013; Tschakert et al. 2007). The village head, secretary, and other village leaders (three to five individuals per village) helped to define wealth categories in these rural communities (Table 1); cattle numbers took precedence in the event of conflicting criteria. The rural household questionnaires sought information on lusala use, tuber collection, consumption, and trade, together with perceptions of $D$. hirtiflora populations in the wild. Each interview lasted about $45 \mathrm{~min}$. The sampling frame was the list of all households in each village provided by the village head, the sampling unit was a household, and the unit of observation was a woman (wife to the household head if married, or female head if not).

A preliminary scoping study indicated that the lusala collection occurs from March to October with July-August the peak collection months. Hence, the surveys were conducted in JulyAugust 2017. The recall method (Angelsen and Lund 2011) was used to estimate collection, consumption, and sale: tubers were initially collected in local units (commonly used measuring plates and buckets) and, on each day of the survey, converted to SI units $(\mathrm{kg})$ after weighing the local unit with a scale. Not all households surveyed provided estimates of the quantities of tubers collected, consumed, or sold. In addition to tuber sale prices, information on sales of maize, the staple crop grown by many farmers in Zambia, was also sought from rural households for comparative purposes.

Three focus group discussions (in Pemba, Namwala, and Itezhi Tezhi) were held after the surveys to collect information that would be difficult to acquire using closed or structured questions, and to add further understanding and reflection to the study. Youths (19-35 years), adults (3565 years), and elders ( $>65$ years) of both genders contributed to each focus group of nine discussants, covering all key survey questions to supplement understanding from questionnaire responses. Four key questions follow:

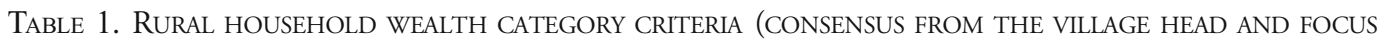
Group DisCussions) In SOUTHERN PROVINCE, Zambia.

\begin{tabular}{llll}
\hline \hline & Criterion & & Poor \\
\cline { 2 - 4 } & Rich & Intermediate & $1-3$ \\
\hline House size (rooms) & $>4$ & $1-3$ & Thatch \\
Roof & Iron sheet or asbestos & Iron sheet or asbestos & Chickens only \\
Livestock & $>5$ cattle & $<5$ cattle or goats or sheep & Nil \\
Sanitation & Blair or flushable toilet & Blair toilet & Nil \\
Power supply & Solar lighting/electricity & Solar lighting/electricity & \\
\hline
\end{tabular}


1. Why is lusala sought after?

2. What variation in tuber morphology have you observed?

3. Have wild lusala populations increased, declined, or remained similar over the past 10 years?

4. If changed, what are the reasons and can you rank them?

\section{Market Trader Survey}

The traders' questionnaire requested information on the value and quantity of $D$. hirtiflora tubers traded. Markets in three towns (Makalanguzu market, Choma; Hamusonde market, Monze; and Nakambala market, Mazabuka) were selected. A total of 21 traders participated. One research assistant was recruited in each district market to collect data from traders for 14 consecutive days in August 2017. Focus group discussions were also held with market traders to complement the survey by exploring reasons underlying the perceptions recorded.

\section{Data ANAlyses}

IBM SPSS (version 24) was used to analyze the results. Descriptive statistics (percentages) were calculated to determine the proportion of households collecting, consuming, and trading lusala tubers. Chi-square tests of independence were performed to determine whether the proportions of households' collection, consuming, or trading tubers differed by districts or wealth categories. Weights of tubers collected, consumed, and traded were transformed to logarithms, to normalize the data, and analysis of variance was performed to evaluate the effect of district or wealth category on tuber collection, consumption, or trading. Pearson product moment correlations were performed to assess possible associations amongst seven variables: number of lusala collection trips, time taken to reach lusala hotspots, quantity collected, time taken to harvest all tubers, quantity consumed, quantity sold, and income earned.

Relative activity month-by-month for lusala collection and engagement in crop production were determined by each household from a scale of 0 to 10 (no activity [0] to greatest activity [10]): 10 stones were provided to each interviewee to enable this rating. Rural households were surveyed on the value of tubers sold. In addition, information on the value of maize sales was also sought from the participants in order to assess the relative value of income from the WEP and this major crop.

Means and percentages were calculated for market traders' reports of tuber weights purchased and costs of purchase, and the challenges they encountered, respectively. Data of the mean weight $(\mathrm{kg})$ and cost of purchase (USD) of lusala tubers were collected over a 14-day period in August 2017 from three district markets in Choma, Monze, and Mazabuka. The traders' perception of lusala demand was measured on a five-point Likert scale (very low to very high demand). Multiple responses were collected for sources of the tubers sold by traders. The mean perceived monthly (January to December) level of trade in lusala was assessed on a scale of 0 to 10 .

Both surveys sought information on the education of household heads; grades on leaving school were recorded. Tuber prices are reported in USD. These were converted from the local currency Zambian Kwacha at the rate USD $1=$ ZMW 10.

Focus group discussions were synthesized to identify emerging themes and categories. The discussants suggested several drivers of decline in lusala populations and were asked to rank these in the order of importance.

\section{Results}

\section{Importance of Lusala to RuRal Households}

The majority of the 278 rural households interviewed were headed by males, of whom $64.3 \%$ or $19.8 \%$ had attended primary or primary and basic school, respectively (Table 2). The average household size was seven. Some $90 \%$ of participating households were either Tonga or Ila; the remaining households were from the Lozi, Kaonde, Bemba, Nyanja, Soli, and Bunda ethnic groups. All three wealth categories were well represented; intermediatewealth households were the largest group.

Dioscorea hirtiflora tubers were gathered from the wild almost throughout the year, with the most activity from March to September peaking in April (Fig. 2a). This coincided with a quiet period for normal crop production activities (land preparation to harvest). The pattern of tuber collection across the year was similar amongst districts (Fig. 2b).

In every district, lusala collection from the wild was dominated by women (mothers), often helped by young girls and elderly ladies, typically grandparents or aunts (Fig. 3). Five to eight tuber collection 
Table 2. Summary of the characteristics of RURAL households SURVEYed IN SOUTHERn ProvinCe, ZAMBIA.

\begin{tabular}{|c|c|c|}
\hline$\overline{\text { Characteristic }}$ & Category & Number (\%) \\
\hline \multirow[t]{4}{*}{ Household district } & Pemba & $78(28.1)$ \\
\hline & Itezhi Tezhi & $74(26.6)$ \\
\hline & Namwala & $78(28.1)$ \\
\hline & Kalomo & $48(17.3)$ \\
\hline \multirow[t]{3}{*}{ Household wealth } & Rich & $73(26.3)$ \\
\hline & Intermediate & $113(40.6)$ \\
\hline & Poor & $90(13.2)$ \\
\hline Household size & & $7.2 \pm 0.2$ \\
\hline \multirow[t]{8}{*}{ Household ethnicity } & Tonga & $155(57.0)$ \\
\hline & Ila & $88(32.4)$ \\
\hline & Lozi & $12(4.4)$ \\
\hline & Kaonde & $9(3.3)$ \\
\hline & Bemba & $5(1.8)$ \\
\hline & Soli & $1(0.4)$ \\
\hline & Bunda & $1(0.4)$ \\
\hline & Nyanja & $1(0.4)$ \\
\hline \multirow[t]{2}{*}{ Household head gender } & Male & $187(67)$ \\
\hline & Female & $91(33)$ \\
\hline Household head age, mean (years) & & $44.1 \pm 0.8$ \\
\hline \multirow[t]{3}{*}{ Household head age, distribution } & Young $(<36$ years $)$ & $66(26.4)$ \\
\hline & Middle (36-65 years) & $167(66.8)$ \\
\hline & Elder (> 65 years) & $17(6.8)$ \\
\hline \multirow[t]{5}{*}{ Household head, education } & None & $14(5.3)$ \\
\hline & Primary $\left(1-7^{*}\right)$ & $169(64.3)$ \\
\hline & Basic $\left(8-9^{*}\right)$ & $52(19.8)$ \\
\hline & Secondary $\left(10-12^{*}\right)$ & $26(9.9)$ \\
\hline & Tertiary & $2(0.8)$ \\
\hline
\end{tabular}

$\pm=$ standard error of mean

*School grade

trips were made by households in the peak collection month in every district, with durations to the collection site varying more than threefold amongst districts (Table 3). Households in Pemba made the fewest collections, were the quickest to gather $1 \mathrm{~kg}$ of tubers, but took the longest to reach $D$. hirtiflora hotspots. In contrast, those in Kalomo were at the opposite extreme for each variable. There were no significant differences amongst districts in the number of collection trips $(F[3,206]=1.76, p=0.16)$ or time required to harvest $1 \mathrm{~kg}$ of tubers $(F[3$, $121]=0.59, p=0.63)$ in the peak month. The time to walk to lusala hotspots varied amongst districts ( $F$ $[3,224]=15.29, p=0.001)$; post hoc comparisons using the Tukey-Kramer test detected differences between Kalomo (the shortest travel time) and the other three districts and between Pemba (the longest travel time) and Itezhi Tezhi.

Consumption of lusala by rural households was ubiquitous, with most engaged in collection, whilst a majority also sold tubers (Fig. 4). Some $83 \%$ of the households in the study sites collected tubers in the peak month, with no difference in this proportion amongst districts $\left(\chi^{2}=0.75, p=0.86\right.$, Fig. $\left.4 \mathrm{a}\right)$, wealth categories $\left(\chi^{2}=5.1, p=0.08\right.$, Fig. $\left.4 \mathrm{~b}\right)$, or gender of the head of household $\left(\chi^{2}=0.13\right.$, $p=0.72)$. Almost all households $(96 \%)$ consumed tubers, with no difference amongst districts $\left(\chi^{2}=\right.$ 2.2, $p=0.53$, Fig. $4 \mathrm{c})$, wealth categories $\left(\chi^{2}=3.20\right.$, $p=0.20$, Fig. $4 \mathrm{~d})$, or gender $\left(\chi^{2}=1.509, p=0.22\right)$. Finally, some $59 \%$ of the households surveyed sold tubers. This did not differ amongst districts $\left(\chi^{2}=\right.$ 7.03, $p=0.71$, Fig. 4e), wealth categories $\left(\chi^{2}=\right.$ $1.36, p=0.51$, Fig. $4 \mathrm{f})$, or gender $\left(\chi^{2}=0.02\right.$, $p=0.88)$.

Mean weights of tubers collected, consumed, and sold in April for those households engaged in each task who reported quantities were $27.9 \mathrm{~kg} \pm 3.5 \mathrm{~kg}$, $12.0 \mathrm{~kg} \pm 1.4 \mathrm{~kg}$, and $35.7 \mathrm{~kg} \pm 6.6 \mathrm{~kg}$, respectively (Fig. $4 \mathrm{~g}-\mathrm{l})$. These estimates were derived only from 


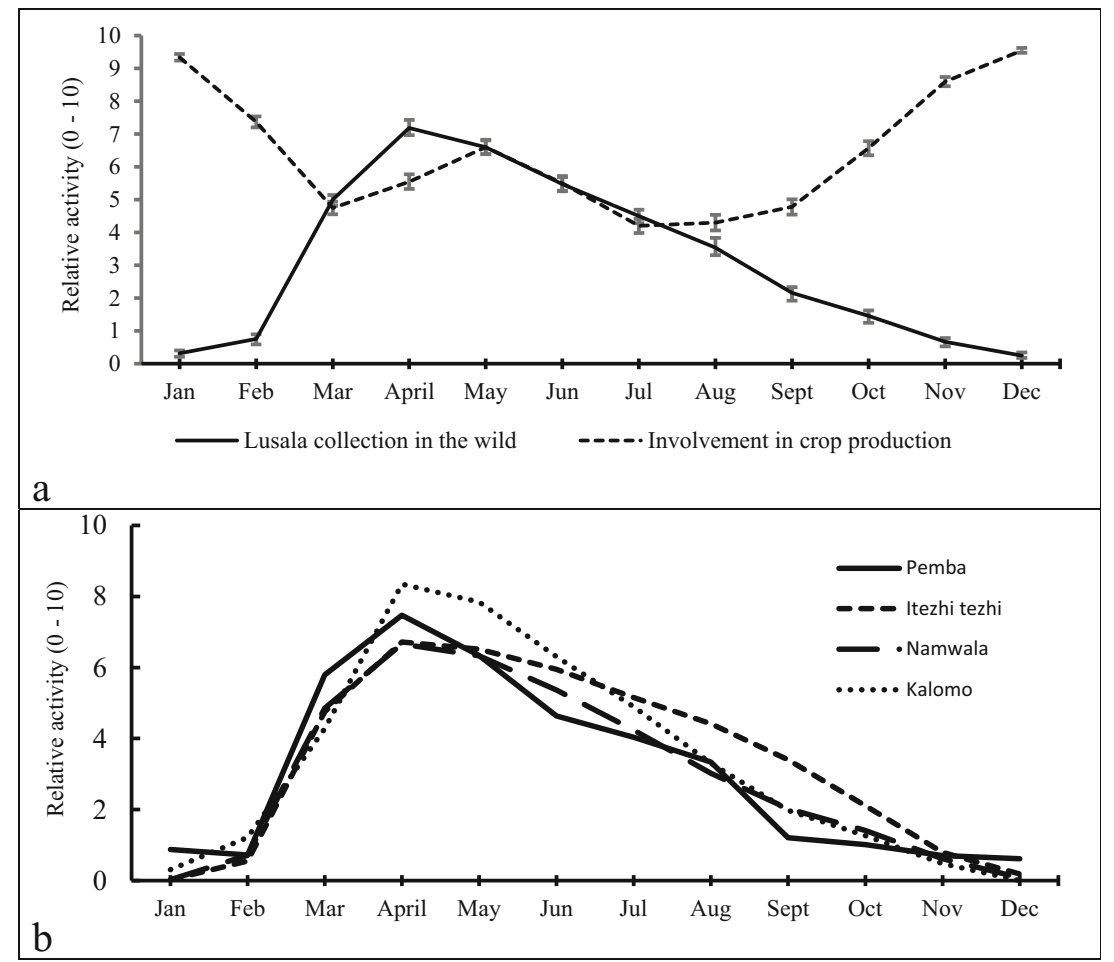

Fig. 2. Comparison across the year of rural household engagement in $D$. hirtiflora tuber collection versus crop production (a) in the Southern Province of Zambia (all districts; vertical bars show \pm standard error of the mean) or (b) amongst the four districts.

data of 129, 108, and 69 households, respectively. The weights of tubers collected did not differ amongst districts $(F[3,128]=2.63, p=0.53$, Fig. $4 \mathrm{~g})$, wealth categories $(F[2,128]=2.67, p=$ 0.73 , Fig. $4 \mathrm{~h})$, or gender of the head of household $(F[1,129]=0.88, p=0.35)$. Neither did weights consumed differ between districts $(F[3,106]=$ $2.23, p=0.09$, Fig. $4 \mathrm{i})$, wealth categories $(F[2$, $106]=2.02, p=0.14$, Fig. $4 \mathrm{j})$, or gender $(F[1$, $107]=2.20, p=0.14)$. Finally, no differences were detected for weights sold amongst districts $(F[3$, $68]=0.46, p=0.71$ Fig. $4 \mathrm{k})$, wealth categories $(F$ $[2,68]=1.24, p=0.30$, Fig. 41$)$, or gender $(F[1$, $69]=0.03, p=0.86$ ). In the case of wealth categories, this was despite mean tuber weights for collection and consumption each appearing to show rich $>$ intermediate $>$ poor (Fig. $4 \mathrm{~h}, \mathrm{j}$ ) and rich $>$ intermediate or poor for tubers sold (Fig. 4l).

Lusala was consumed by rural households $0.71 \pm 0.73$ times in the 7 days preceding interviews, with no differences $(F[2,271]=0.33, p=$ $0.72)$ amongst wealth groups.
Most households in Pemba and Namwala sold tubers at village markets whereas district markets were used more in Itezhi Tezhi and Kalomo (Fig. 5). Few households sold tubers through wholesalers to market traders. The value of $D$. hirtiflora tubers sold ranged widely, from USD 0.6 to USD 128 per household selling tubers in the peak collection month, averaging USD $16.14 \pm 3$.5. The average sale price for rural households ranged from USD $0.35 / \mathrm{kg}$ in Kalomo to USD 0.49/kg in Itezhi Tezhi. These households in the four districts also reported an average income of USD $192.49 \pm 27.16$ from sales of maize each year.

Focus group discussions confirmed the value and importance of $D$. hirtiflora, with the good taste of tubers highlighted ("lusala is tasty;" "it blends well with groundnuts, eggs, fish, and meat") in all three districts (Table 4). They also reported that tuber palatability, food value, and quality are low during the rainy season. Tuber texture changes then, and so they become difficult to cook (described locally as kusaba in Tonga). Moreover, whilst collection 


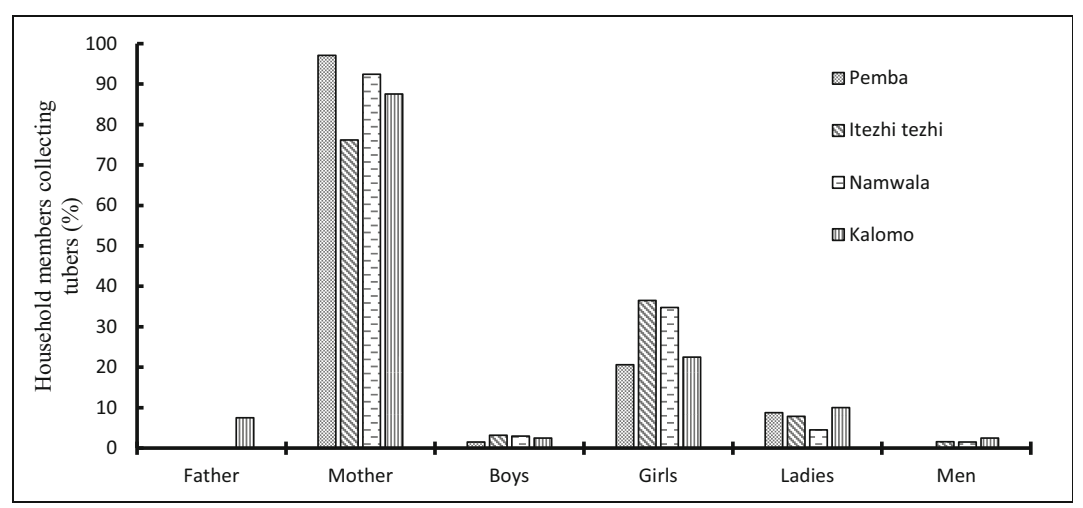

Fig. 3. Household members (multiple responses) collecting D. hirtiflora tubers in the Southern Province of Zambia. Ladies or men refer to other elderly household adult members.

peaked in April, this was considered too early to collect good quality tubers because they retained high water content. Early tuber collection before the end of the rainy season was due to high competition amongst collectors. The best quality tubers were reported to be collected after June, when moisture has been lost, until tubers lose dormancy. The occurrence of male and female plants (dioecy) in $D$. hirtiflora was identified in all four districts. Several different aspects of tuber morphology were also identified, with Pemba identifying the greatest range. The focus groups suggested associations between tuber color and soil type and of high rainfall with hairy tubers and greater water content.

The associations amongst seven variables concerning $D$. hirtiflora collection, consumption, and sale by rural households are presented in Table 5. Other than time to hotspots not being correlated with any other variable, most of these associations provided significant correlations. In particular, the more time dedicated to gathering tubers once a collector has arrived at a hotspot, the more tubers harvested $(r=0.63)$, the more tubers consumed $(r=0.52)$, the more tubers sold $(r=0.60)$, and the more earned from tuber sales $(r=0.72)$.

\section{Status of Lusala Populations in the Wild}

Most households (79\%) perceived populations of D. hirtiflora to be declining in the wild, which $98 \%$ ascribed to overharvesting. This was attributed to human population growth. Other causes suggested included deforestation due to charcoal production, clearing forests for new crops, unsustainable harvesting, and declining rainfall.

The focus groups also ranked overharvesting as the top cause of loss of $D$. hirtiflora in the wild (Table 6). Elders were well aware of the importance of sustainable tuber collection practices. They explained that in the past, they ensured that small tubers and rhizomes were re-buried after gathering, with only larger tubers removed from the forest for consumption. Discussants suggested that the decline in sustainable practices was linked to the pressure to collect quickly amid increasing competition for resources that are a common asset. Limited farmer-led cultivation activities were revealed in Pemba, only, where some farmers deliberately gather and plant rhizomes and tubers in protected gardens or in forests near their homes. All focus groups identified lack of appropriate

TABLE 3. Number Of COLleCtion trips, TIME TO WALK TO THE NEAREST $D$. HIRTIFLORA HOTSPOT IN THE FOREST, AND TIME TO HARVEST 1 KG OF TUBERS, IN THE PEAK COLLECTION MONTH OF APRIL ( \pm SEM) SURVEYED IN SOUTHERn Province, Zambia.

\begin{tabular}{lccc}
\hline \hline Districts & Collection trips in peak month & Walking time to hotspot (min) & Time to harvest 1 kg (min) \\
\hline Pemba & $5.4 \pm 0.7$ & $123 \pm 9.7$ & $19.6 \pm 2.9$ \\
Itezhi Tezhi & $6.2 \pm 0.8$ & $72 \pm 7.0$ & $40.0 \pm 7.0$ \\
Namwala & $5.9 \pm 0.7$ & $95 \pm 8.0$ & $43.6 \pm 6.4$ \\
Kalomo & $8.1 \pm 1.1$ & $36 \pm 5.9$ & $43.6 \pm 8.3$ \\
\hline
\end{tabular}



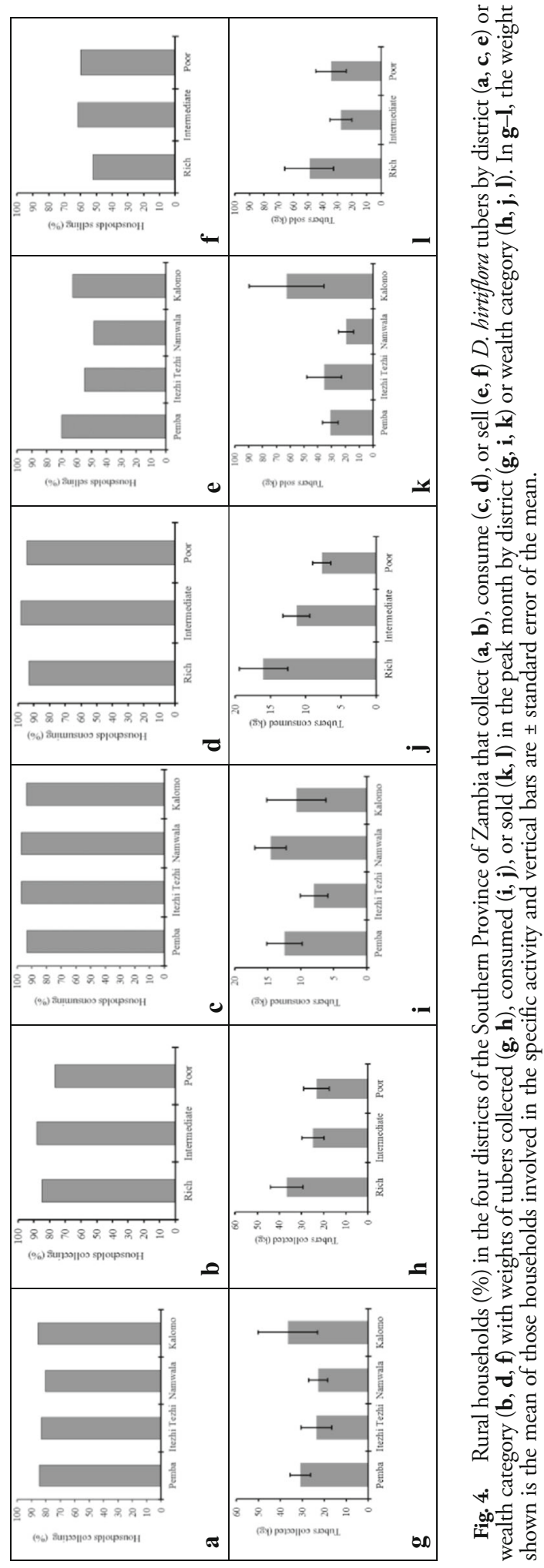


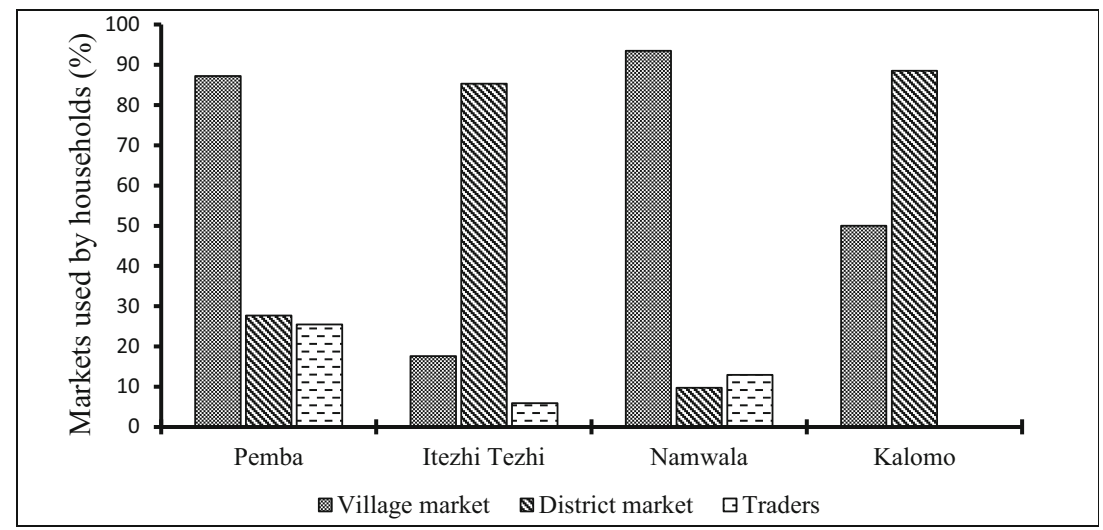

Fig. 5. Sales outlets (multiple responses) used by rural households who sold $D$. hirtiflora tubers in each district within the Southern Province of Zambia.

knowledge as one reason why farmers do not cultivate $D$. hirtiflora (Table 4).

\section{IMPORTANCE OF LUSALA TO MARKET TRADERS}

All traders in the district market study were women, and almost all are Tongas (Table 7). Half of the trader households were female-headed. During a 14-consecutive day period in August 2017, on average, each trader purchased $419.0 \mathrm{~kg} \pm 22.7 \mathrm{~kg}$ of tubers for USD $178.7 \pm 13.24$ from collectors and wholesalers. Those in Monze traded lower weights of tubers at a higher unit price on average than those in either Choma to the southwest or Mazabuka to the northeast (Fig. 6a). Almost all traders rated customer demand for tubers as moderately high or very high (Fig. 6b).

Most tubers sold in these markets (Makalanguzu market in Choma, Hamusonde market in Monze, and Nakambala market in Mazabuka) were gathered from Mulobezi District in Western Province (Fig. 6c), over $250 \mathrm{~km}$ from Choma. The smallest

TABLE 4. FOCUS GROUP REASONS $(\checkmark=$ YES; $X=$ NO) FOR VALUING TUBERS, CHARACTERISTICS IDENTIFIED, AND NOT Cultivating D. hirtiflora in the three districts in Southern Province, Zambia.

\begin{tabular}{llll}
\hline \hline & Pemba & Itezhi Tezhi & Namwala \\
\hline Why tubers valued & & $\sqrt{ }$ & $\sqrt{ }$ \\
Good taste & $\sqrt{ }$ & $\sqrt{ }$ & $\mathrm{x}$ \\
Blends easily/well with other foods & $\sqrt{ }$ & $\mathrm{x}$ & $\sqrt{ }$ \\
Income generation $_{\text {High energy content }}$ & $\mathrm{x}$ & $\mathrm{x}$ & $\sqrt{ }$ \\
Tuber characteristic & & $\mathrm{x}$ & $\sqrt{ }$ \\
Light-skinned tubers ${ }^{1}$ & $\sqrt{ }$ & $\sqrt{ }$ & $\sqrt{ }$ \\
Dark-skinned tubers & $\sqrt{ }$ & $\sqrt{ }$ & $\mathrm{x}$ \\
Short tubers with fewer hairs & $\sqrt{ }$ & $\mathrm{x}$ & $\mathrm{x}$ \\
Long hairy tubers & $\sqrt{ }$ & $\sqrt{ }$ & $\sqrt{ }$ \\
Watery tubers & $\sqrt{ }$ & $\sqrt{ }$ & $\sqrt{ }$ \\
Drier tubers & $\sqrt{ }$ & $\sqrt{ }$ & $\sqrt{ }$ \\
Male and female plants & $\sqrt{ }$ & $x$ & $x$ \\
Reasons for non-cultivation & $\sqrt{ }$ & $\sqrt{ }$ & $x$ \\
No knowledge of cultivating plants & $\sqrt{ }$ & $\sqrt{ }$ \\
Potential destruction by wild pigs & $x$ & & $\sqrt{ }$ \\
Avathering by neighboring farmers & & & \\
\hline
\end{tabular}

${ }^{1}$ Tuber skin color was said to be influenced by soil type

${ }^{2}$ Seen as a resource for all since it is a wild plant 
TABLE 5. CORRELATIONS AMONGST THE SEVEN VARIABLES FOR D. HIRTIFLORA COLLECTION, CONSUMPTION, AND INCOME (IN PEAK COLLECTION MONTH) IN SOUTHERN PROVINCE, ZAMBiA.

\begin{tabular}{|c|c|c|c|c|c|c|}
\hline$\overline{\overline{\text { Variable }}}$ & $\overline{1} 1$ & $\overline{2}$ & 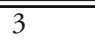 & $\overline{4}$ & $\overline{5}$ & $\overline{66}$ \\
\hline 1. Number of collection trips & - & & & & & \\
\hline 2. Time to reach hotspot & ns & - & & & & \\
\hline 3. Quantity collected & $0.29^{* *}$ & ns & - & & & \\
\hline 4. Time to harvest all tubers & $0.44^{* *}$ & $\mathrm{~ns}$ & $0.63^{* *}$ & _- & & \\
\hline 5. Quantity consumed & ns & $\mathrm{ns}$ & $0.53^{* *}$ & $0.52^{* *}$ & - & \\
\hline 6. Quantity sold & $0.24^{*}$ & $\mathrm{~ns}$ & $0.92^{* *}$ & $0.60^{* *}$ & $0.61^{* *}$ & - \\
\hline 7. Income & $0.42^{* *}$ & $\mathrm{~ns}$ & $0.79^{* *}$ & $0.72^{* *}$ & $0.42^{* *}$ & $0.78^{* *}$ \\
\hline
\end{tabular}

ns not significant $(p>0.05)$

${ }^{*} p<0.05 ;{ }^{* *} p<0.01$

fraction of tubers was from Kapiri Mposhi District, Central Zambia, over $320 \mathrm{~km}$ away, whilst the remaining tubers were from within the Southern Province, including the areas of Masuku, Singani (both 20-30 km from Choma Town), and Namwala (170 km from Choma Town).

Tuber sales peaked in May to August (Fig. 6d) and were sold at USD $0.63-0.77 \mathrm{~kg}^{-1}$. Traders purchased tubers from wholesalers at an average of USD $0.43 \mathrm{~kg}^{-1}$. The challenges encountered by district market traders included rotting of older tubers $(35 \%)$, high wholesale prices (29\%), itching after washing and packing tubers $(24 \%)$, unpredictable business $(18 \%)$, increasing scarcity of the tubers $(6 \%)$, or the work washing tubers $(6 \%)$.

\section{Discussion}

Yams are exploited as cultivated crops across Africa, Asia, South America, the Caribbean, and the Pacific Islands, with 93\% of world yam production in West Africa (Asiedu and Sartie 2010). The collection of wild yams is less well documented (Kumar et al. 2017; Majule et al. 2010), but wild yam collection has been reported in Southern Africa (Wilkin 2001).

Local knowledge of $D$. hirtiflora in the Southern Province of Zambia was considerable: focus group members possessed considerable depth of knowledge; most rural households also knew much about the plant. Some wild yam species can be toxic to humans (Poornima and Ravishankar 2009). Indeed, there is a report that Dioscorea hirtiflora is toxic but it also notes that it is gathered from the wild and eaten and used medicinally in West Africa (Fern 2018). Lusala from the Southern Province of Zambia, however, does not appear to be toxic: local people sometimes chew it raw. Part of the cultural knowledge and inter-generational training identified within focus group discussions was the correct identification of lusala by collectors to avoid collecting other, similar

TABLE 6. REASONS FOR THE DECLINE OF D. HIRTIFLORA POPULATIONS IN THE WILD SUGGESTED BY THREE DISTRICT FOCUS GROUPS IN SOUTHERN PROVINCE, ZAMBIA.

\begin{tabular}{|c|c|c|c|c|c|c|c|}
\hline \multirow[t]{2}{*}{$\overline{\overline{\text { Reason }}}$} & \multicolumn{2}{|l|}{ Namwala } & \multicolumn{2}{|c|}{ Itezhi Tezhi } & \multicolumn{2}{|l|}{ Pemba } & \multirow[t]{2}{*}{$\overline{\overline{\text { Overall rank }}}$} \\
\hline & Identified & Rank & Identified & Rank & Identified & Rank & \\
\hline Overharvesting* & $\sqrt{ }$ & 1 & $\sqrt{ }$ & 3 & $\sqrt{ }$ & $2=$ & \\
\hline Opening up new crop fields & $\sqrt{ }$ & 4 & $\sqrt{ }$ & 1 & $\sqrt{ }$ & 4 & 2 \\
\hline Unsustainable harvesting & $\sqrt{ }$ & 3 & $\mathrm{x}$ & - & $\sqrt{ }$ & 1 & $3=$ \\
\hline Declining rainfall & $\sqrt{ }$ & 2 & $\mathrm{x}$ & - & $\sqrt{ }$ & $2=$ & $3=$ \\
\hline Clearing forests for homesteads & $\mathrm{x}$ & - & $\sqrt{ }$ & 2 & $\mathrm{x}$ & - & 5 \\
\hline Cutting down trees for charcoal & $\sqrt{ }$ & 6 & $\sqrt{ }$ & 5 & $\sqrt{ }$ & 5 & $6=$ \\
\hline Consumption by wild pigs & $\sqrt{ }$ & 5 & $\mathrm{x}$ & - & $\mathrm{x}$ & - & $6=$ \\
\hline Limited food options & $\mathrm{x}$ & - & $\sqrt{ }$ & 4 & $\mathrm{x}$ & - & 8 \\
\hline
\end{tabular}

$\sqrt{ }$, identified; $x$, not identified; $=$, the same ranking

*Due to population growth and tuber demand 
TABle 7. Household Characteristics of market traders Surveyed in SOUtHern ProvinCe, Zambia.

\begin{tabular}{lll}
\hline \hline Characteristic & Category & Number (\%) [range] \\
\hline Traders in market (town) & Makalanguzu (Choma) & $9(43)$ \\
& Nakambala (Mazabuka) & $5(24)$ \\
& Hamusonde (Monze) & $7(33)$ \\
Household head gender $^{1}$ & Male & $10(50)$ \\
& Female & $10(50)$ \\
Household ethnicity ${ }^{1}$ & Tonga & $18(90)$ \\
& Lozi & $1(5)$ \\
Household size & Kaonde & $1(5)$ \\
Household head age (years) & & $5.1 \pm 0.45$ \\
Household head school grade & & $39.3 \pm 2.9[21-62]$ \\
Period trading (years) & & $8.8 \pm 0.66$ \\
\hline
\end{tabular}

${ }^{1}$ Of the 20 responses

(but potentially toxic), plants. Collectively, these observations contrast with the general expectation that traditional knowledge of NTFPs held by indigenous peoples has declined (van den Boog et al. 2017), perhaps because of lusala's continued regional significance in not only rural household diets but also those of urban populations nearby.

A high proportion of rural households across all four districts collected and consumed wild D. hirtiflora tubers, with over half also selling tubers. The tubers are highly sought after for energy, ability to blend with other foods, and good taste. There was no evidence from this study that lusala was exploited for anything other than food.

This high utilization of wild $D$. hirtiflora tubers corroborates other studies showing high use of and dependence upon culturally valued WEPs amongst rural households (Bakkegaard et al. 2017; Heubach et al. 2011; Kalaba et al. 2013; Paumgarten and Shackleton 2009; Shelef et al. 2017). For example, 90\% of households in Zambia's Copperbelt Province obtained WEPs from forests with $72 \%$ of households collecting wild mushrooms but far fewer collecting roots and tubers (Kalaba et al. 2013). Tradition and associated local cultural perceptions, attitudes, and beliefs often influence the type of plants utilized in each community with some WEPs said to be gathered, especially during hunger periods when crops fail, out of economic desperation (Agustino et al. 2011). In contrast, D. hirtiflora tubers were collected for positive reasons, associated at least in part with local food culture, in this study in Zambia's Southern Province; as a traditional delicacy of the Tonga people; and often to supplement rural household incomes. Lusala is not a poverty plant, therefore. This conclusion is well supported by the substantial engagement of the wealthiest rural households in its collection, consumption, and sale (Fig. 4).

Household tuber collection and consumption were independent of the gender of household heads, wealth category, or district. This agrees with some studies showing that wealth and household head gender do not influence the use of certain NTFPs (Kalaba et al. 2013; Paumgarten and Shackleton 2009; Shackleton and Shackleton 2004). The relationship between wealth and NTFP use is mixed and complex (Paumgarten and Shackleton 2009). In Zimbabwe, for example, wealthy households consumed more environmental resources (Cavendish 2000) (as found here for weights of lusala, albeit not significantly so). Nonetheless, the poorer tend to be more resource dependent in proportional terms (Angelsen et al. 2014; Cavendish 2000) but are less reliant on NTFPs for cash income (Angelsen et al. 2014).

In cultivated yam (Dioscorea rotundata Poir.), food quality declines once tubers sprout, with the collection period associated with tuber dormancy (Ile et al. 2006). Similarly, the March through August lusala collection period (Fig. 2) occurs towards the end of the rainy and throughout the dry seasons, with poor quality tubers at other times.

The study only collected information on quantities of lusala tubers collected in the peak collection month. Moreover, many households surveyed were unable to answer the quantitative questions on tuber weights. In order to better define this WEP's economic value, our preliminary estimate of total tuber collection from March to October could be improved upon by frequent (weekly) surveys using the recall method or by supporting participating 


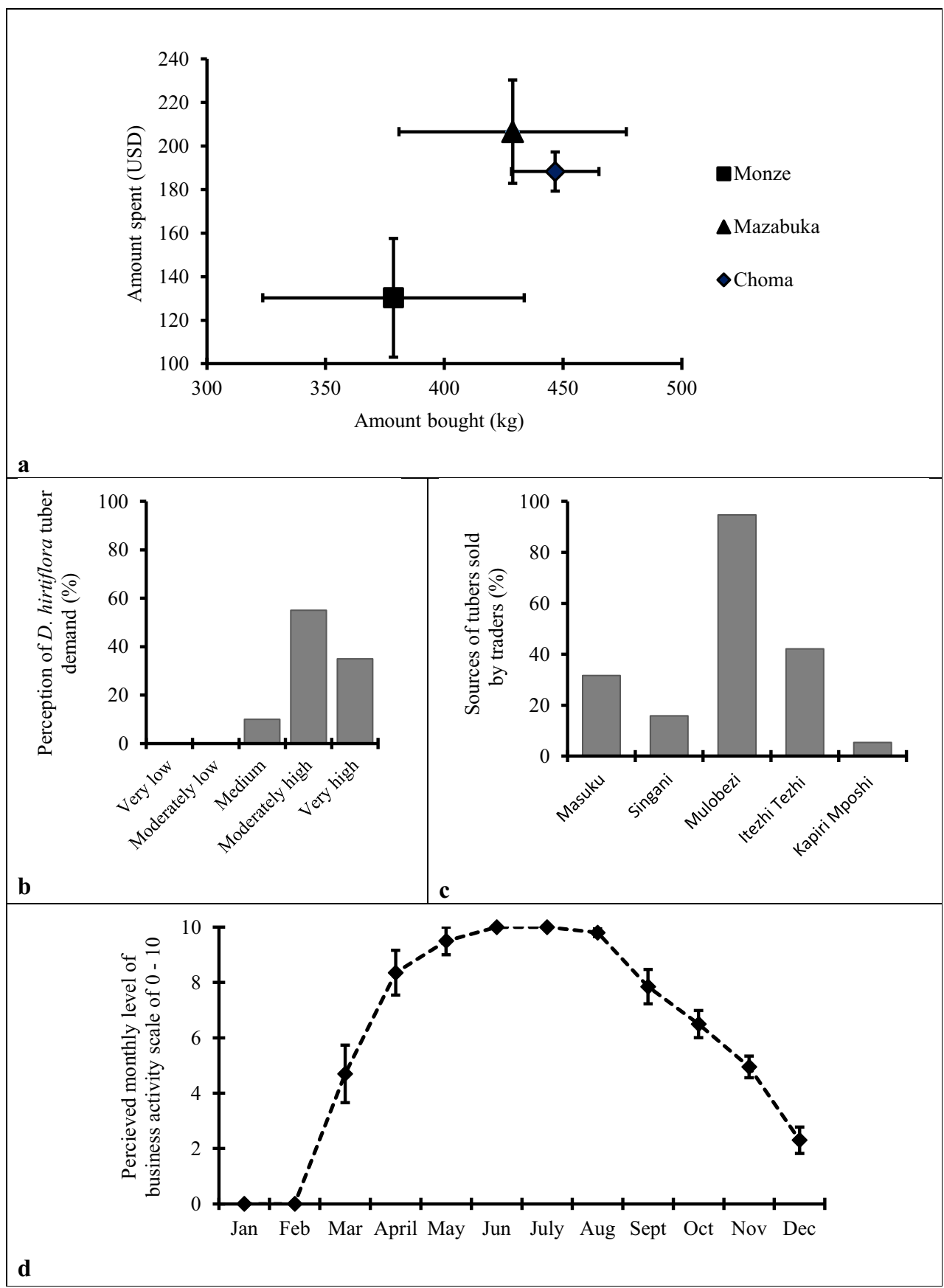

Fig. 6. Summary of the survey of market traders in district markets within each of the towns of Choma, Monze, and Mazabuka in the Southern Province of Zambia; total weight and cost of purchase (USD) of D. hirtiflora tubers reported for a 14-day period in August 2017 (a, horizontal and vertical bars show \pm standard error of the mean); traders' perception of demand for D. hirtiflora tubers in these markets (b, Likert scale); source of tubers reported by traders (c, multiple responses; Masuka and Singani are villages near Choma; Mulobezi is in Western Province; Kapiri Mposhi is in Central Province, Fig. 1); and relative monthly level of tuber trade (scale of $0-10)$ reported by traders (d, vertical bars show \pm standard error of the mean). 
households to record daily activities. A future survey also should seek information on tuber purchases by, and bartering for tubers, amongst rural households, both from other rural households and markets. This omission, together with the different numbers of households reporting in each category, explains why the average weights of tubers consumed and sold per household exceeded that for those collected. The wholesale price of tubers paid by traders was, on average, greater than that received by rural households. This is not surprising given the wholesalers in the supply chain, but this is not discussed further because the prices were for different months. Rural households used many different types of market (Fig. 5), and traders purchased tubers from distant provinces (Fig. 6c).

The study areas in Namwala, Pemba, and Itezhi Tezhi were under customary land tenure, whereas Kalomo was under statutory land tenure (formal land registration). Customary land tenure is characterized by communal ownership of forest resources, whereas forests are privately owned in statutory lands (Mulolwa 2006). The study area in Kalomo was a private commercial tobacco farm; households interviewed worked on the farm, and the landowner allowed tuber gathering from the forest. This forest was better conserved than the other three areas, possibly because tree felling was forbidden and strictly enforced, and provided the shortest walk to $D$. hirtiflora hotspots. The long collection time there was due to competition from other collectors at this remaining hotspot (where the plants were reported to be at low density). The contrast with Pemba implies that the much longer walk there limited competition for tubers amongst those collectors who reached the hotspot. The lack of correlation between walking time to the $D$. hirtiflora hotspots and other variables (Table 5) implies that the tubers' high value to rural households justifies long collection trips.

The collection of $D$. hirtiflora tubers was dominated by females (Fig. 3). Women tend to dominate the gathering of WEPs (Kalaba et al. 2013; Kiptot and Franzel 2012; Shackleton and Shackleton 2004), and they are often more knowledgeable about such resources than men (Agustino et al. 2011). Whereas most rural households were headed by males, the market trader households were equally male- and female-headed. We speculate that market trading may offer such urban women an independent income; there is a long history of successful market trading by women throughout Africa (Sheldon 2017).

The current study allows a preliminary estimate of the annual income to households selling lusala in Southern Province to be made, albeit based on several assumptions. If (1) the April tuber price reported by households was to apply year-round (underestimating prices in other months, presumably) and (2) relative engagement in tuber sales was the same as collection (Fig. 2a), the average annual income from tubers would be USD 85.28.

NTFPs may contribute significantly to rural household incomes: for example, 44\% in Zambia's Copperbelt (Kalaba et al. 2013), 39\% in Ethiopia (Mamo et al. 2007), and 35\% in Zimbabwe (Cavendish 2000). We did not investigate total household incomes, but a limited single-crop WEP comparison suggests lusala sales income is about $44 \%$ of that of the maize sold by these households. This largely dry season income may be important to household cash flow.

As with the wild medicinal root Anacyclus pyrethrum (L.) Link var. pyrethrum in Morocco (Ouarghidi et al. 2017), for example, almost all interviewees reported that wild populations of $D$. hirtiflora are declining due to overharvesting, which they ascribed to human population growth and deforestation. The population of Zambia more than trebled from 5 million to over 16 million between 1974 and 2016 (Central Statistical Office 2015), and Zambia is losing 250,000 ha to 300,000 ha of forests annually (Mukosha and Siampale 2009). Dioscorea hirtiflora is a common resource where communities appear now (compared to the more sustainable collection practices of previous generations reported by village elders) to have little regard for sustainable utilization. Hence, "the tragedy of the commons" (Hardin 1968) could have played a role in this decline.

The district markets selected for the tuber trader survey are leading produce distribution centers in Southern Province. About 90\% of traders interviewed were Tongas, the markets being in the Tonga ethnic region where the tubers are valued as a food. The study recorded high demand, with tubers purchased from wholesalers each week and some transported from over $300 \mathrm{~km}$ away. The latter might indicate overharvesting has reduced $D$. hirtiflora plant populations in Southern Province and/or high demand from growing urban populations. The high level of trade and long supply chains emphasize the market pull by urban households in Zambia's Southern Province for $D$. hirtiflora tubers. 


\section{Conclusions}

In the Southern Province of Zambia, Dioscorea hirtiflora tubers are collected by the vast majority of rural households, mostly by women. Lusala consumption was ubiquitous: very few rural households do not consume these tubers, and they are an important addition to the seasonal (March-September) diets of almost all, and income of over half, of rural households. They are also in strong demand from expanding urban populations nearby. Populations of $D$. hirtiflora in the wild are, however, reported to be declining due to overharvesting and loss of habitat through deforestation. Preventative action to enable sustainable utilization of lusala is therefore required to support food security. A twintrack approach of research into sustainable lusala collecting and also its domestication may halt plant population decline in the wild, sustain rural livelihoods, and meet the demands of both urban and rural human populations in the Southern Province of Zambia for this culturally significant WEP. Research should build upon the traditional knowledge of sustainable collection of lusala held by village elders across Southern Province, and potentially in Western Province, and on the experience of the few farmers in Pemba District at the forefront of its domestication for crop production. Genetic diversity in D. hirtiflora also should be assessed across Zambia as a prelude to conserving and then utilizing this diversity to develop its agronomic potential, perhaps in novel agroforestry systems.

\section{Acknowledgements}

We thank Keith Hasimuna, Mainza Keembe, Jowana Nkumbu, and Collins Sichimbale for their help in contacting the village leaders, obtaining the research consents, and acting as local guides; Vincent Mofya, Sarah Miti, Mildred Mubu, Stanley Zulu, and Protasius Matongo for their help with the rural household survey; Marvis Siangilichi, Loreta Moonga, and Natasha Mumba for their help with the market survey; Matamyo Simwanda for drawing the maps; and Phosiso Sola of the World Agroforestry Centre (ICRAF), Nairobi, and Felix Kalaba of the Copperbelt University, Kitwe, Zambia, for their advice on the draft questionnaires.

\section{Funding Information}

This research was supported by the award of a research scholarship to DZ by the Commonwealth Scholarship Commission (ZMCS-2016-850).
Open Access This article is distributed under the terms of the Creative Commons Attribution 4.0 International License (ht t p:// creativecommons.org/licenses/by/4.0/), which permits unrestricted use, distribution, and reproduction in any medium, provided you give appropriate credit to the original author(s) and the source, provide a link to the Creative Commons license, and indicate if changes were made.

\section{Literature Cited}

Agustino, S., B. Mataya, K. Senelwa, and G. E. Achigan-Dako. 2011. Non-wood forest products and services for socio-economic development, a compendium for technical and professional forestry education. Nairobi, Kenya: The African Forest Forum.

Angelsen, A. and J. F. Lund. 2011. Designing the household questionnaire. In: Measuring livelihoods and environmental dependence, methods for research and fieldwork, eds. A. Angelsen, H. O. Larsen, J. F. Lund, C. Smith-Hall, and S. Wunder, 107-126. Oxford, U.K.: Earthscan Publications.

Angelsen, A., P. Jagger, R. Babigumira, B. Belcher, N. J. Hogarth, S. Bauch, J. Borner, and C. Smith-Hall. 2014. Environmental income and rural livelihoods: A global-comparative analysis. World Development 64:12-28.

Asiedu, R. and A. Sartie. 2010. Crops that feed the world. Yams for income and food security. Food Security 2:305-315.

Bakkegaard, R. K., N. J. Hogarth, I. W. Bong, A. S. Bosselmann, and S. Wunder. 2017. Measuring forest and wild product contributions to household welfare: Testing a scalable household survey instrument in Indonesia. Forest Policy and Economics 84:20-28.

Baudeon, F., H. M. Mwanza., B. Triomphe, and M. Bwalya. 2007. Conservation agriculture in Zambia: A case study of Southern Province. Nairobi, Kenya: African Conservation Tillage Network, Centre de Coopération Internationale de Recherche Agronomique pour le Développement, Food and Agriculture Organization of the United Nations.

Bharucha, Z. and J. Pretty. 2010. The roles and values of wild foods in agricultural systems. Philosophical Transactions of the Royal Society B 365:2913-2926.

Cavendish, W. 2000. Empirical regularities in the poverty-environment relationship of rural 
households: Evidence from Zimbabwe. World Development 28:1979-2003.

Central Statistical Office. 2012. 2010 Census of population and housing. National Analytic Report, 1-117. Lusaka, Zambia: Central Statistical Office. http://www.zamstats.gov.zm/census/ cen.html. Accessed 27 Nov 2017.

2015. Living conditions monitoring survey report. Lusaka, Zambia: Central Statistical Office. https://www.zamstats.gov.zm/ phocadownload/Living_Conditions/2015\% 20Living\%20Conditions\%20Monitoring\% 20Survey\%20Report.pdf. Accessed 27 Nov 2017.

Fern, K. 2018. Tropical plants database. tropical. theferns.info. Accessed 16 July 2018.

Forestry Department. 2016. Measuring the informal forest-based economy as part of the national forest monitoring and assessment, Integrated Land Use Assessment Phase II - Technical paper 6. Lusaka, Zambia: Ministry of Lands Natural Resources and Environmental Protection, Rome, Italy: Food and Agricultural Organization of the United Nations, and Finland: Ministry of Foreign Affairs.

Hachigonta, S., C. J. C. Reason, and M. Tadross. 2008. An analysis of onset date and rainy season duration over Zambia. Theoretical and Applied Climatology 91:229-243.

Hardin, G. 1968. The tragedy of the commons. Science 162:1243-1248.

Heubach, K., R. Wittig, E.-A. Nuppenau, and K. Hahn. 2011. The economic importance of nontimber forest products (NTFPs) for livelihood maintenance of rural west African communities: A case study from northern Benin. Ecological Economics 70:1991-2001.

Ile, E. I., P. Q. Craufurd, N. H. Battey, and R. Asiedu. 2006. Phases of dormancy in yam tubers (Dioscorea rotundata). Annals of Botany 97:497504.

Kalaba, F. K., C. H. Quinn, and A. J. Dougill. 2013. Contribution of forest provisioning ecosystem services to rural livelihoods in the miombo woodlands of Zambia. Population and Environment 35 159-182.

Kiptot, E. and S. Franzel. 2012. Gender and agroforestry in Africa: A review of women's participation. Agroforestry Systems 84:35-58.

Krejcie, R. V. and D. W. Morgan. 1970. Determining sample size for research activities. Educational and Psychological Measurement 30: 607-610.
Kumar, S., G. Das, H.-S. Shin., and J. K. Patra. 2017. Dioscorea species (a wild edible tuber): A study on its ethnopharmacological potential and traditional use by the local people of Similipal Biosphere Reserve, India. Frontiers in Pharmacology 8:52.

Majule, A. E., E. T. Liwenga, and H. J. Ndangalasi, 2010. Socio-economics of non-wood food forest products to the community in the southern coastal areas of Tanzania. Revista Română de Geografie Politică Year XII 2:309-328.

Mamo, G., E. Sjaastad, and P. Vedeld. 2007. Economic dependence on forest resources: A case from Dendi district, Ethiopia. Forest Policy and Economics 9:916-927.

Mukosha, J. and A. Siampale. 2009. Integrated land use assessment Zambia 2005-2008. Lusaka, Zambia: Ministry of Tourism, Environment and Natural Resources, Forestry Department, and Rome, Italy: Food and Agriculture Organization of the United Nations.

Muliokela, S. W. 1995. Zambia seed technology handbook. Lusaka, Zambia: Ministry of Agriculture, Food and Fisheries.

Mulolwa, A. 2006. Demystifying customary tenure in Zambia, 1-12. Promoting land administration and good governance. 5th FIG Regional Conference, Accra, Ghana, March 8-11, 2006.

Murali, K. S., U. Shankar, R. U. Shaanker, K. N. Ganeshaiah, and K. S. Bawa. 1996. Extraction of non-timber forest products in the forests of Biligiri Rangan Hills, India. 2. Impact of NTFP extraction on regeneration, population structure, and species composition. Economic Botany 50:252-269.

Ouarghidi, A., B. Powell, G. J. Martin, and A. Abbad. 2017. Traditional sustainable harvesting knowledge and distribution of a vulnerable wild medicinal root (A. pyrethrum var. pyrethrum) in Ait M'hamed Valley, Morocco. Economic Botany 71:83-95.

Padulosi, S., J. Thompson, and P. Rudebjer. 2013. Fighting poverty, hunger and malnutrition with neglected and underutilized species (NUS): Needs, challenges and the way forward. Rome, Italy: Bioversity International.

Paumgarten, F. and C. M. Shackleton. 2009. Wealth differentiation in household use and trade in non-timber forest products in South Africa. Ecological Economics 68:2950-2959.

Poornima, G. N. and R. V. Ravishankar. 2009. Evaluation of phytonutrients and vitamin contents in a wild yam, Dioscorea belophylla (Prain) Haines. African Journal of Biotechnology 8:971-973. 
RBG Kew. 2016. The state of the world's plants report-2016. London: Royal Botanic Gardens, Kew.

Shackleton, C. M. and S. E. Shackleton. 2004. The importance of non-timber forest products in rural livelihood security and as safety nets: A review of evidence from South Africa. South African Journal of Science 100:658-664.

Shackleton, C., C. O. Delang, S. Shackleton, and P. Shanley. 2011. Non-timber forest products: Concept and definitions. In: Non-timber forest products in the global context, eds., S. Shackleton, C. Shackleton, and P. Shanley, 3-21. Heidelberg: Springer-Verlag.

Sheldon, K. 2017. African women: Early history to the 21st century. Bloomington: Indiana University Press.

Shelef, O., P. J. Weisberg, and F. D. Provenza. 2017. The value of native plants and local production in an era of global agriculture. Frontiers in Plant Science 8:2069.

Shitumbanuma, V., F. Tembo, J. M. Tembo, S. Chilala, and E. van Ranst. 2007. Dental fluorosis associated with drinking water from hot springs in Choma district in Southern Province, Zambia. Environmental Geochemistry and Health 29:51-58.

Speybroeck, N., M. Madder, P. van den Bossche, J. Mtambo, N. Berkvens, G. Chaka, M. Mulumba, J. Brandt, L. Tirry, and D. Berkvens. 2002. Distribution and phenology of ixodid ticks in southern Zambia. Medical and Veterinary Entomology 16(4):430-441.
Sunderland, T., R. Achdiawan, A. Angelsen, R. Babigumira, A. Ickowitz, F. Paumgarten, V. Reyes-García, and G. Shively. 2014. Challenging perceptions about men, women, and forest product use: A global comparative study. World Development 64: S56-S66.

Tiffen, M. and M. R. Mulele. 1994. The environmental impact of 1991-92 drought on Zambia. Gland, Switzerland: IUCN.

Timko, J., P. Waeber, and R. Kozak. 2010. The socio-economic contribution of non-timber forest products to rural livelihoods in Sub-Saharan Africa: Knowledge gaps and new directions. International Forestry Review 12:284-294.

Tschakert, P., O. T. Coomes, and C. Potvin. 2007. Indigenous livelihoods, slash-and-burn agriculture, and carbon stocks in Eastern Panama. Ecological Economics 60:807-820.

van den Boog, T., T. van Andel, and J. Bulkan. 2017. Indigenous children's knowledge about non-timber forest products in Suriname. Economic Botany 71:361-373.

Vinya, R., S. Syampungani, E. Kasumu, C. Monde and R. Kasubika. 2011. Preliminary study on the drivers of deforestation and potential for REDD+ in Zambia. A consultancy report prepared for the Forestry Department and FAO under the National UN-REDD+ Programme. Lusaka, Zambia: Ministry of Lands \& Natural Resources.

Wilkin, P. 2001. Dioscoreaceae of south-central Africa. Kew Bulletin 56:361-404. 